\title{
Analysis of the 1998 to 2005 drought over the northeastern highlands of Tanzania
}

\author{
Agnes L. Kijazi ${ }^{1,2}$, C. J. C. Reason ${ }^{1, *}$ \\ ${ }^{1}$ Oceanography Department, University of Cape Town, Rondebosch 7701, South Africa \\ ${ }^{2}$ Tanzania Meteorological Agency, PO Box 3056, Dar es Salaam, Tanzania
}

\begin{abstract}
Extreme weather and climate events have major negative effects on Tanzania's economy. Recently, the prolonged drought from 1998 to 2005 caused devastating crop failures, livestock losses and reductions in the country's water reservoir levels, which, in turn, created food shortages and rationing of hydroelectric power and water. The present study analyses the atmospheric circulations associated with the 1998 to 2005 drought that affected the northeastern highlands of Tanzania. Analysis of large-scale circulation indicates that the drought during the October to December (OND) short rainy seasons, from 1998 to 2005, was related to westerly low-level moisture flux divergence and subsidence over northern Tanzania associated with an eastward shift of the Walker cell. For the March to May (MAM) long rainy seasons, the prolonged drought was related to strong moisture flux divergence over the region and subsidence associated with the occurrence of the descending branch of a Walker-type circulation over the region. Rainfall onset was undefined for most years in both the OND and the MAM seasons, and, in all cases, unevenly distributed rains with prolonged dry spells were experienced in a shorter than average rainy season. However, an out-of-season rainfall peak occurred in January, after the end of the OND rains. This delayed peak has important implications for agricultural and water resource activities. The circulation patterns observed in the Tanzanian region from 1998 to 2005 were similar to those experienced during a previous prolonged drought (1973 to 1976), suggesting that some predictability of drought may exist.
\end{abstract}

KEY WORDS: Drought · Africa $\cdot$ Circulation anomaly

\section{INTRODUCTION}

In the recent past, Tanzania has experienced pronounced climate variability that has had major negative effects on various sectors of the economy, including agriculture, health, food security, energy and other key socio-economic sectors of the country. The most recent cases were floods in 1997 and 2006 and drought from 1998 to 2005. In all instances, these had devastating effects, most notably crop failures and livestock losses, that resulted in major food shortages. Another major effect was the reduction in the level of the country's water reservoirs, which resulted in hydroelectric power and water rationing. This caused socio-economic hardships and negative economic growth rates. To minimise the adverse effects of climate variability, it is necessary to understand more fully the mechanisms involved and to improve long-range rainfall prediction efforts for the region.

Rain-fed agriculture is the mainstay of the Tanzanian economy. Climate is therefore one of the most important factors in determining the agricultural potential of the country. Various researchers have studied drought patterns in East Africa and their potential impacts on the economy (e.g. Nieuwolt 1978, Ininda 1984, Ogallo \& Nassib 1984, Mhita 1990, Ogallo \& Ambenje 1996). Ogallo (1984) reported that East Africa is, on average, drought free for only 21 out of 100 yr. Extreme rainfall anomalies are common in East Africa, and some of these are localised, while others cover a larger area and persist for several seasons or years (Ogallo \& Ambenje 1996). A good example is the drought over 
the northeastern highlands of Tanzania (the area around Mt Kilimanjaro) that persisted from 1998 to 2005. However, little attention has been given to drought events in specific regions in Tanzania, and the present study aims to bridge that knowledge gap by analysing the 1998 to 2005 protracted drought over the northeastern highlands of Tanzania.

The region experiences 2 distinct rainfall seasons; the March/April/May (MAM) long rains, traditionally known as the 'masika' rains, and the October/ November/December (OND) short rains, known as the 'vuli' rains (Figs. 1 \& 2a), which are related to the movement of the inter-tropical convergence zone (ITCZ). The terms short and long rainfall seasons refer to the respective times taken for the ITCZ to migrate between the Southern and Northern Hemispheres. The ITCZ generally takes longer to move northwards in boreal spring than it does to migrate southwards in austral spring. This difference may be related to the presence of larger land masses in the Northern Hemisphere that lose heat faster than the larger ocean areas in the Southern Hemisphere with their greater thermal inertia. The lag period between the latitudinal cycle of the sun and the ITCZ is usually 2 mo (Riehl 1979). Christina et al. (2002) found that these 2 rainy seasons do not correlate significantly with each other and are thus relatively independent. Over East Africa, the short rains (OND) have shown a larger degree of interannual variability relative to climatology than have the MAM rains (Hastenrath et al. 1993).

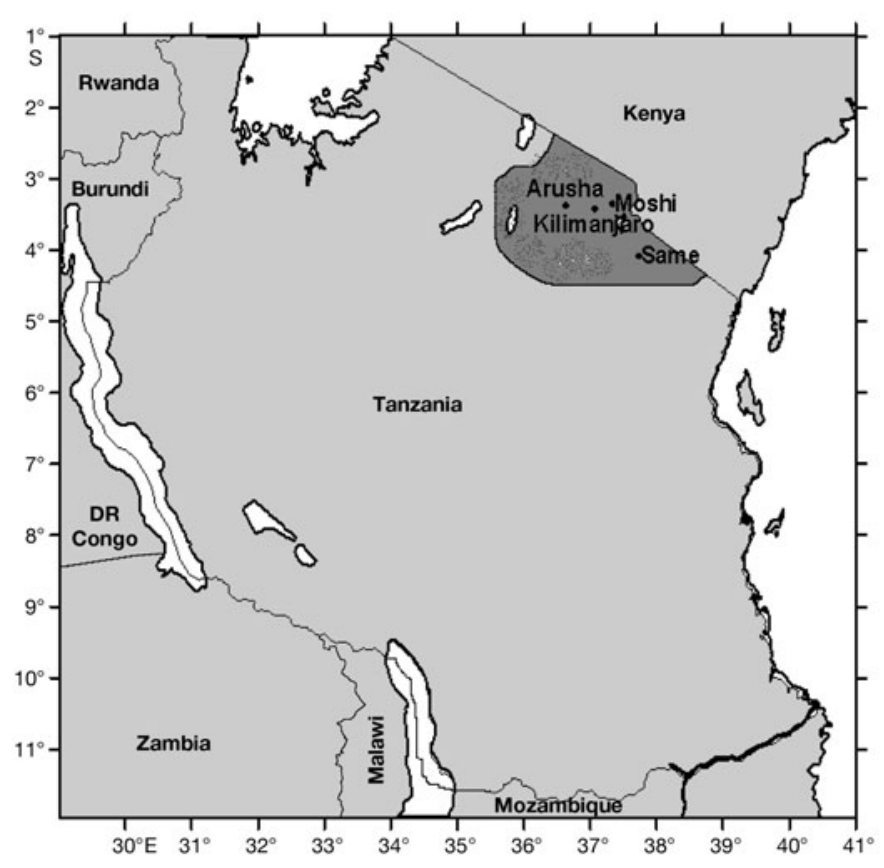

Fig. 1. Region of study (shaded) and rainfall stations used in the present study
Ogallo (1989), Nyenzi (1992) and Kabanda \& Jury (1999) established that the El Niño/Southern Oscillation (ENSO) has an influence on the occurrence of drought in Tanzania. Some extreme rainfall events in East Africa have been significantly associated with ENSO (e.g. Stoeckenius 1981, Ropelewski \& Halpert 1987, Janowiak 1988, Ogallo 1988, Kiladis \& Diaz 1989, Nicholson \& Entekhabi 1989, Goddard \& Graham 1999). Typically, rainfall tends to be enhanced (reduced) over equatorial East Africa during El Niño (La Niña) events (e.g. Camberlin 1995, Nicholson 1996, Reason et al. 2000, Kijazi \& Reason 2005). Nieuwolt (1978) and Minja (1982) found droughts to be associated with weak monsoons. Ogallo (1984) attributed the occurrence of droughts over the country to the position of the ITCZ. Recent investigations have provided evidence of anomalous events in the tropical Indian Ocean that point to the existence of coupled modes of interaction between the ocean and the atmosphere over this basin (Anderson 1999). This Indian Ocean zonal dipole mode (IOZDM) significantly influences the rainfall of eastern Africa during the austral spring/early autumn (Saji et al. 1999, Webster et al. 1999). Hastenrath et al. (2007) associated the 2005 drought that occurred over Equatorial East Africa with subsidence over the region.

During the prolonged 1998 to 2005 drought, substantial decreases in crop yields and pasture for animals were reported. The poor rainfall led to significantly reduced pasture and water availability, resulting in massive emaciation including deaths of livestock. The International Federation of the Red Cross issued an emergency appeal to support about 75000 people affected by drought over the northeastern highlands (DIA 2006). The present study gives a detailed description of the atmospheric circulation associated with the persistent 1998 to 2005 drought over the northeastern highlands of Tanzania. A better understanding of the impacts of climate variability in the region may assist with farm management and the resulting crop yields. To achieve more sustainable agricultural production, it is important for policy makers and economists to understand and accept the variability of climate, both inter-annually and intra-seasonally, so as to utilise natural resources efficiently.

In order to address the aims, the present study analyses rainfall distribution over the northeastern highlands of Tanzania on seasonal and intra-seasonal time scales, which are significant for crop water requirements at different phenological phases. It gives a detailed analysis of intra-seasonal rainfall distribution and the major circulation features responsible for the prolonged drought over the region. The following section discusses the methodology and data, while Section 3 provides a detailed discussion of inter-annual vari- 
ability. Section 4 outlines intra-seasonal variability, and the last section gives the conclusions.

\section{DATA AND METHODS}

To understand the temporal and spatial behaviour of rainfall over the northeastern highlands of Tanzania, daily and monthly totals for 4 stations (in the area around Mt Kilimanjaro) were obtained from the Tanzania Meteorological Agency for the 1970 to 2005 period. These stations were Arusha, Moshi, Kilimanjaro International Airport and Same (Fig. 1). All stations had continuous records, used the same type of rain gauge and remained at the same observational site during this period. Rainfall indices for the OND and the MAM seasons were computed from the standardised departures of the seasonal rainfall averaged over the stations. Similar standardised rainfall anomaly indices have been used in previous research to assess the intensity of rainfall anomalies in East Africa (e.g. Ogallo
\& Nassib 1984, Kabanda \& Jury 1999, Kijazi \& Reason 2005, Mapande \& Reason 2005).

The time series of rainfall departures for 1970 to 2005 climatology were plotted for both the OND and MAM seasons (Fig. 2b,c). Both series indicated negative anomalies for the period of study (1998 to 2005), with the exception of MAM and OND of 2002, which was an El Niño year and consequently received aboveaverage rainfall.

For each season, the daily rainfall data were converted from daily to $5 \mathrm{~d}$ averages (pentads), to reduce noise associated with day-to-day variability. Time series of pentad rainfall data for the period from 1970 to 2005 were used to derive climatological dates for the onset, peak and cessation of the OND and MAM rainy seasons and for dry spells within these seasons. Similarly, time series for each year within the study period (1998 to 2005) were plotted, and the within-season rainfall characteristics were derived. The series for each year was compared with climatology to understand the departure of each year from this field.
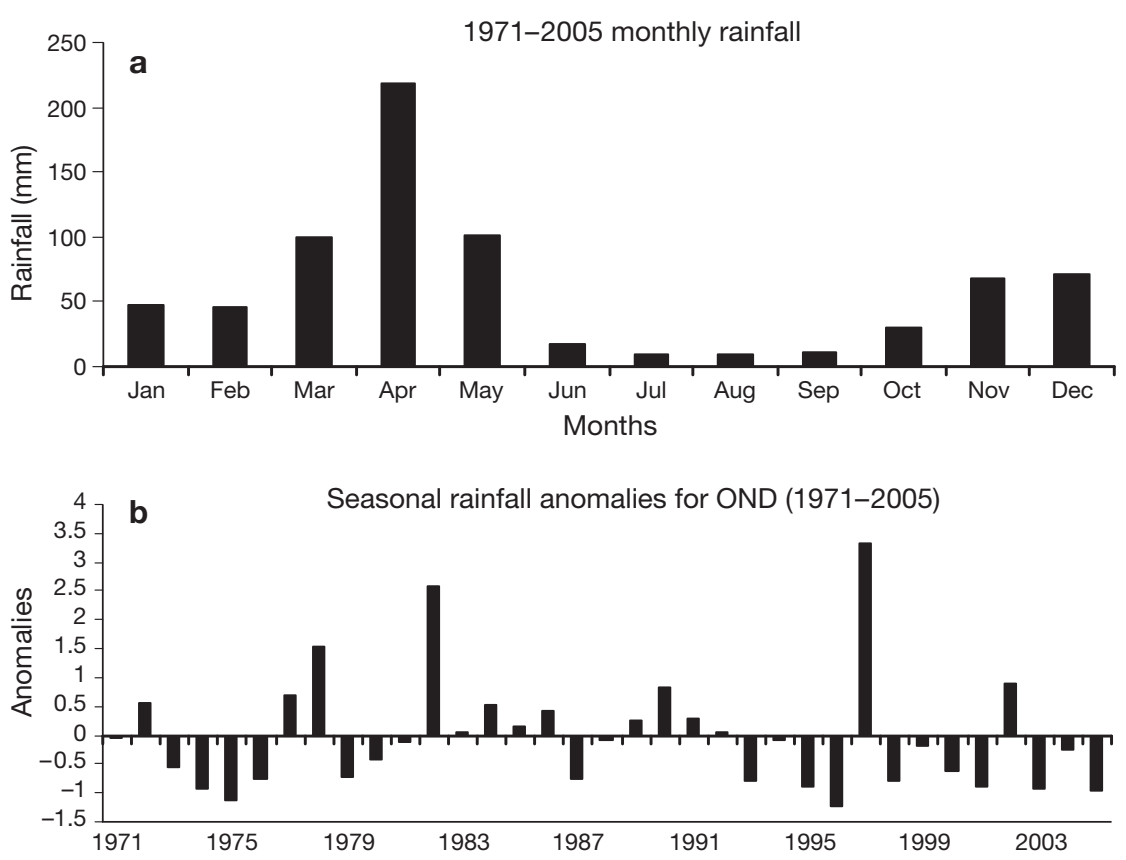

Fig. 2. (a) Time series of the annual rainfall cycle $(\mathrm{mm})$ and standardised rainfall departures for (b) the OND (October, November, December) season and (c) the MAM (March, April, May) season over the northeastern highlands of Tanzania

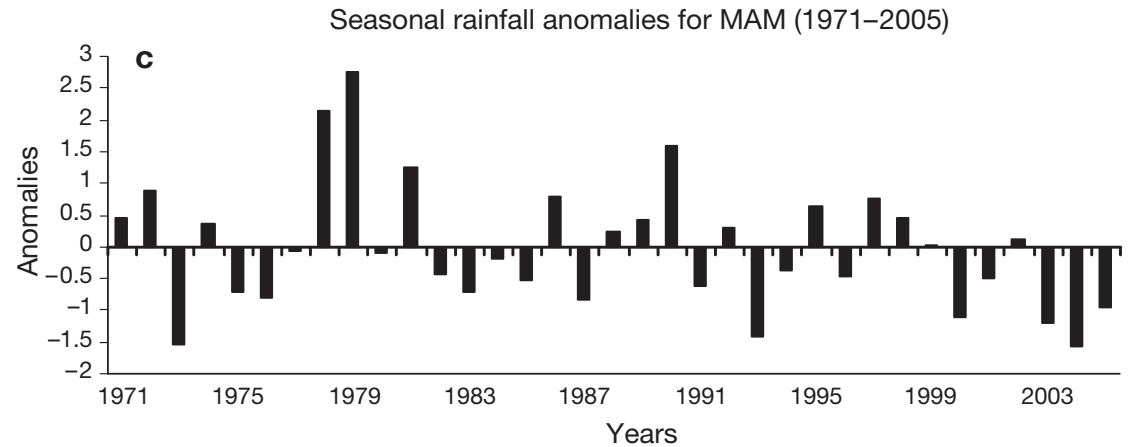


To analyse the spatial variability of rainfall over Tanzania, the CPC Merged Analysis of Precipitation (CMAP) data were used; i.e. merged satellite, rain gauge and model precipitation estimates discussed in Xie \& Arkin (1997). These data are gridded with a resolution of $2.5 \times 2.5^{\circ}$. Monthly mean values were used to calculate anomalies.

The NCEP-NCAR reanalysis data (Kalnay et al. 1996) were used for analyses of atmospheric circulation patterns associated with the drought. The anomalies were calculated from the 1970 to 2005 climatology. Specifically, there is an interest in understanding the role of wind and moisture flux circulation patterns in modulation of the Tanzanian climate.

The horizontal moisture flux for a given level can be obtained from the product of specific humidity and the horizontal wind vector. In the tropics, most of the horizontal moisture flux takes place below $700 \mathrm{hPa}$ (Newell et al. 1972). The low-level tropospheric wind field can, therefore, determine most of the moisture transport. Earlier studies, e.g. Goddard \& Graham (1999), observed the $850 \mathrm{hPa}$ level to be the most representative of the behaviour of the vertically integrated moisture flux over East Africa. Based on this idea, the $850 \mathrm{hPa}$ level was used in this research for analyses of moisture flux.

Chen \& Yen (1991) have shown that the velocity potential at $200 \mathrm{hPa}$ is a useful meteorological parameter in tropical climate studies. Velocity potential and stream function may be more useful than divergence and vorticity, since they are components of the horizontal circulation wind vector and give useful representations in the tropics, where mean winds are light. The physical properties of the horizontal 2-D wind field $(V)$ can be described by considering the rotational and irrotational terms, also known as non-divergent and divergent wind. respectively.

Thus, $V=v_{\psi}+v_{\mathrm{X}}$, where $v_{\psi}$ is the stream function (rotational) part of the wind, while $v_{X}$ is the velocity potential (irrotational) part (Krishnamurti et al. 1973). The velocity potential is useful for inferring changes in the large-scale vertical circulation and the Walker cell, and has been used by various researchers for East African problems (e.g. Kabanda \& Jury 1999, Mistry \& Conway 2003).

\section{INTERANNUAL VARIABILITY}

\subsection{Time series analysis}

The normalised rainfall departures for OND and MAM are shown in Fig. 2b,c. OND 1973 to 1976 and 1998 to 2005 can be identified as 2 periods of prolonged drought in the region. Prolonged wet periods are less evident in the record, although 1982 to 1986 represents a series of average or above-average OND rainfall seasons. However, the record is also characterised by individual OND seasons that had much greater wet departures (e.g. 1978, 1982, 1997) compared to the negative departures. Note that 1982 and 1997 correspond to the positive phase of the IODZM, coinciding with an El Niño event.

Despite 2002 being a wet year with a standardised rainfall anomaly value of about 0.8 , the period from 1998 to 2005 stands out as featuring one of the worst droughts in recent decades over Tanzania. Almost the entire country experienced at least 2 consecutive dry years during this period. However, longer periods of drought were observed over the northern part of the country, specifically the northeastern highlands.

During the MAM season (Fig. 2c), the region experienced more dry years than wet. The 1998 to 2005 drought over the region occurred in both the OND and MAM seasons, although for MAM it started in 2000 rather than 1998. As for OND, the seasons of strong positive rainfall departures (e.g.1978, 1979) tend to be larger in magnitude than seasons of negative departures.

The strongest OND drought in the region was experienced in 2005, with a standardised rainfall anomaly value of -0.95 , followed by 2003, which had an anomaly value of -0.92 . However, the 2003 OND dry season was preceded by a MAM 2003 drought (standardised value of about -1.2) and was followed by the driest season in MAM 2004, with a standardised anomaly value of -1.57 , making the impact of the 2003/2004 drought particularly devastating.

\subsection{Large-scale climate forcing}

The analysis in this section considers the seasonal anomalies for moisture flux, wind, vertical velocity and velocity potential fields during the OND and MAM seasons of the composites. As 2002 experienced aboveaverage rainfall, it was excluded from the compositing procedure. The 1998 to 2005 period was composited for the OND season, while 2000 to 2005 was combined for the MAM season. To ensure that the results were not biased by particular years within the study period, some seasons (e.g. 2005 and 2003 OND; 2004 MAM) were excluded from the compositing procedure, and the results were compared. However, it was found that there were no significant differences between the results. This implies that the years considered in the composite have similar seasonal atmospheric circulation despite the fact that, in terms of rainfall onset and duration, each year has its own characteristics (see Section 4). The results present the composite anomaly 
values from the 1970 to 2005 climatology. The lowlevel moisture flux convergence and areas of uplift are shaded in the moisture flux divergence and omega plot, respectively. Analysis of the 1973 to 1976 prolonged drought was also done for comparison.

The $850 \mathrm{hPa}$ level moisture flux was analysed to identify the areas of moisture flux divergence that contributed to the drought. Velocity potential and omega (pressure tendency and hence vertical velocity) was analysed to identify areas of low-level subsidence and possible shifts in the position of Walker-type circulation that were associated with the drought. The shift in the descending and ascending branches of the Walker circulation has also been linked to rainfall variability over East Africa (Bjerknes 1969, Webster 1983).

\subsubsection{OND circulation}

Fig. 3a illustrates the OND low-level moisture flux circulation derived for the 1970 to 2005 period. Strong easterly moisture flux is apparent over the southwestern Indian Ocean between 20 and $5^{\circ} \mathrm{S}$, with westerly anomalies in the vicinity of the equator. The moisture flux convergence plot (Fig. 3b) indicates convergence over western Tanzania and divergence

a
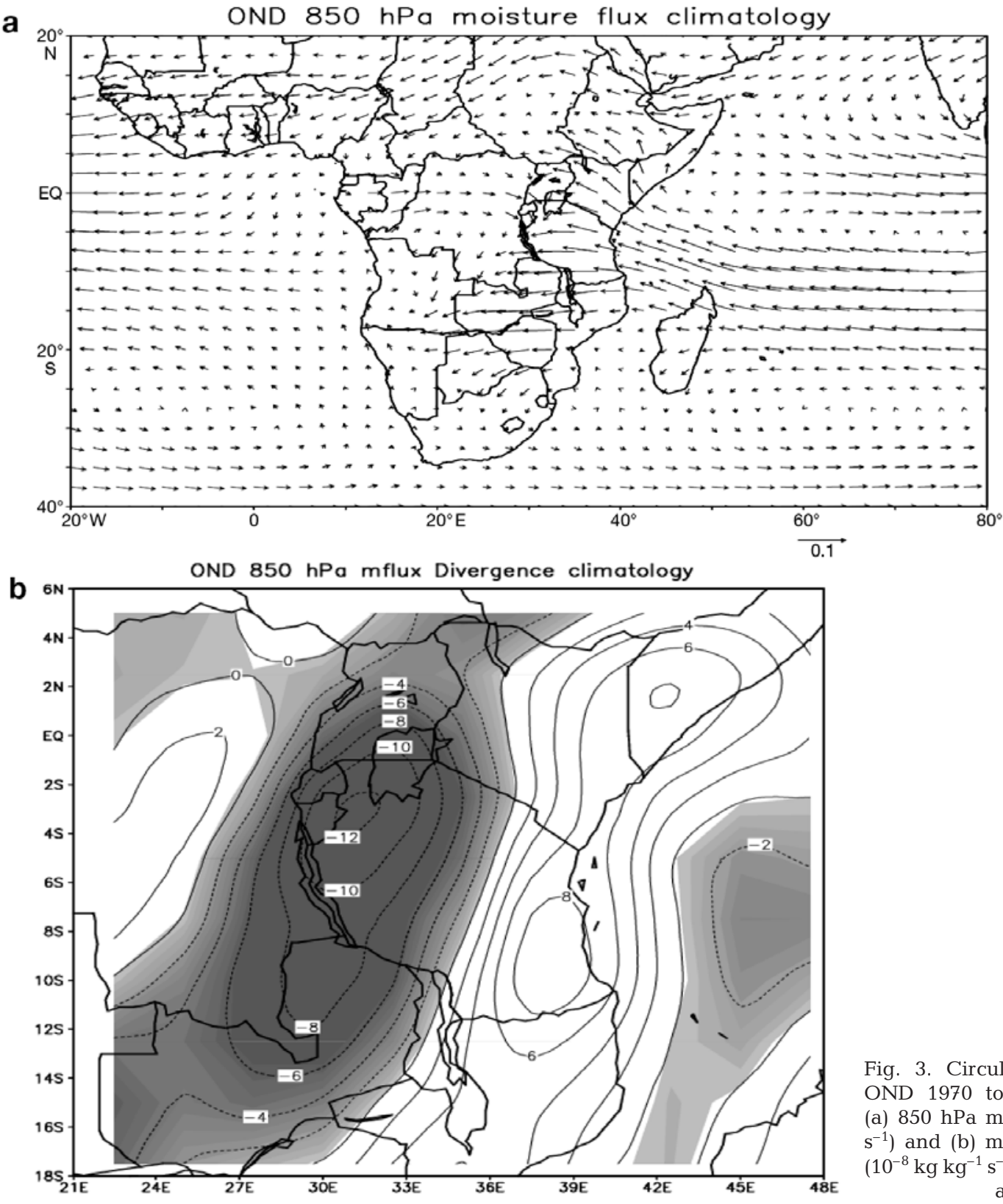

Fig. 3. Circulation patterns for the OND 1970 to 2005 climatology for: (a) $850 \mathrm{hPa}$ moisture flux $\left(\mathrm{kg} \mathrm{kg}^{-1} \mathrm{~m}\right.$ $\mathrm{s}^{-1}$ ) and (b) moisture flux divergence $\left(10^{-8} \mathrm{~kg} \mathrm{~kg}^{-1} \mathrm{~s}^{-1}\right)$. Areas of convergence are shaded 
over eastern Tanzania. The low-level divergence field might be significantly influenced by the coastal topography, such that most of the rainfall observed over eastern Tanzania may result from the interaction between the moist easterly trades and orography (Kijazi \& Reason 2005).

Fig. 4 illustrates rainfall, moisture flux and wind composite anomaly fields for the OND 1998 to 2005 period. Much of the rainfall fell over the western Indian Ocean and southern Tanzania, leaving the northern part of the country dry. A rainfall anomaly value of about $-1.0 \mathrm{~mm} \mathrm{~d}^{-1}$ occurred over the Lake Victoria Basin, with below-average rainfall over the northeastern highlands of Tanzania, consistent with the ongoing drought (Fig. 4a). Fig. 4b indicates an anticyclonic moisture flux anomaly over the equatorial western Indian Ocean, with strong westerly anomalies between the equator and $10^{\circ} \mathrm{S}$ and easterly anomalies over the Congo Basin. These moisture flux patterns divert moisture away from Tanzania.

At the $850 \mathrm{hPa}$ level, the northeasterly moisture flux (Fig. 4b) and wind (not shown) anomalies covered much of Kenya. The wind accelerated overland and backed to westerly anomalies as it approached the Tanzanian coast. Most of Tanzania and the equatorial western Indian Ocean were covered with westerly (i.e. offshore) wind anomalies, consistent with the observed drought. Furthermore, the easterly wind anomalies over the Congo Basin also transported moisture away from Tanzania. Westerly wind anomalies emanating from the Atlantic Ocean occurred over much of western and southern Tanzania, consistent with the above-average rainfall observed (Fig. 4a). The offshore westerly wind anomalies over the equatorial western Indian Ocean strengthen the mean moisture transport away from the country. Using a Lagrangian method, Nieto et al. (2006) examined the sources of moisture over the Sahelian region for a period of $5 \mathrm{yr}$ (2000 to 2005). Their results indicated that the Indian Ocean was not a significant moisture source for the Sahel, consistent with the strong westerly anomalies observed over Tanzania during this period.

Camberlin \& Wairoto (1997) indicated that during wet conditions over East Africa, the northeasterly monsoonal flow switches to easterly over the region. Consistent with their results, Fig. $4 \mathrm{c}$ indicates that dry conditions over Tanzania from 1998 to 2005 were associated with northeasterly flow backing into northwesterly flow over the country. Further north, over the western Indian Ocean, easterly wind anomalies observed over 5 to $10^{\circ} \mathrm{N}$ veer into southeasterly anomalies as they approach the Somali coast. The northeasterly anomalies over Kenya and northern Tanzania originate from Ethiopia and are therefore dry. Again, westerly wind anomalies from the Atlantic Ocean cover much of western and southern Tanzania. Such wind configuration patterns are consistent with the observed dry conditions over the northeastern highlands of Tanzania.

The low- to mid-level westerly wind anomalies are identified by the zonal wind transect averaged over the region (Fig. 5a). A westerly anomaly value of about $0.6 \mathrm{~m} \mathrm{~s}^{-1}$ is evident at $850 \mathrm{hPa}$ and opposes the mean easterly winds. At $200 \mathrm{hPa}$, an easterly anomaly value of about $1.0 \mathrm{~m} \mathrm{~s}^{-1}$ opposes the climatological westerlies and implies upper-level convergence. However, in both cases, the anomalies and associated upper-level convergence are weak, consistent with the relatively weak negative rainfall anomalies over the region. Okoola (1999) showed that easterly anomalies in the upper levels are associated with dry conditions over East Africa. Fig. 5b shows moisture flux divergence over northern and northeastern Tanzania, consistent with dry conditions.

The anomalies in velocity potential and omega for OND 1998 to 2005 can be seen in Fig. 6. Note that omega indicates the rate of change of pressure with time, and therefore negative (positive) values imply relative ascent (descent). The position of the ascending limb of the local Indian Ocean Walker cell is located over Indonesia and Papua New Guinea at about $140^{\circ} \mathrm{E}$, as indicated by the positive velocity potential and convergent wind in the lower levels (Fig. 6a). This pattern is coupled with negative velocity potential and divergent wind in the upper levels (Fig. 6b). Such lower and upper-level atmospheric circulation patterns suggest a slight eastward shift of the ascending branch of the Walker circulation (Webster 1983). Subsidence covers much of the equatorial western Indian Ocean closer to the East African coast and northern Tanzania, as indicated by the omega plot (Fig. 6c), which is consistent with the observed drought. Consistent with our study, Hastenrath et al. (2007) found the 2005 drought over equatorial East Africa to be associated with subsidence over the region and westerly wind.

Comparison of Figs. 4b \& 5b with Fig. 7 shows that the OND 1973 to 1976 prolonged drought experienced similar circulation patterns to the 1998 to 2005 drought. Thus, Fig. 7 also shows easterly moisture flux anomalies over the northwestern Indian Ocean backing to northeasterly anomalies over Somalia and Kenya and running parallel to the coast over Tanzania. Similar moisture flux circulation features were observed during OND 1973 to 1976 and for OND 1998 to 2005, except for the westerly moisture flux anomaly over the northern Congo Basin observed during the former case. Fig. $7 \mathrm{~b}$ indicates moisture flux divergence over northern and western Tanzania, with stronger anomalies centred over the northeastern highlands of Tan- 
a

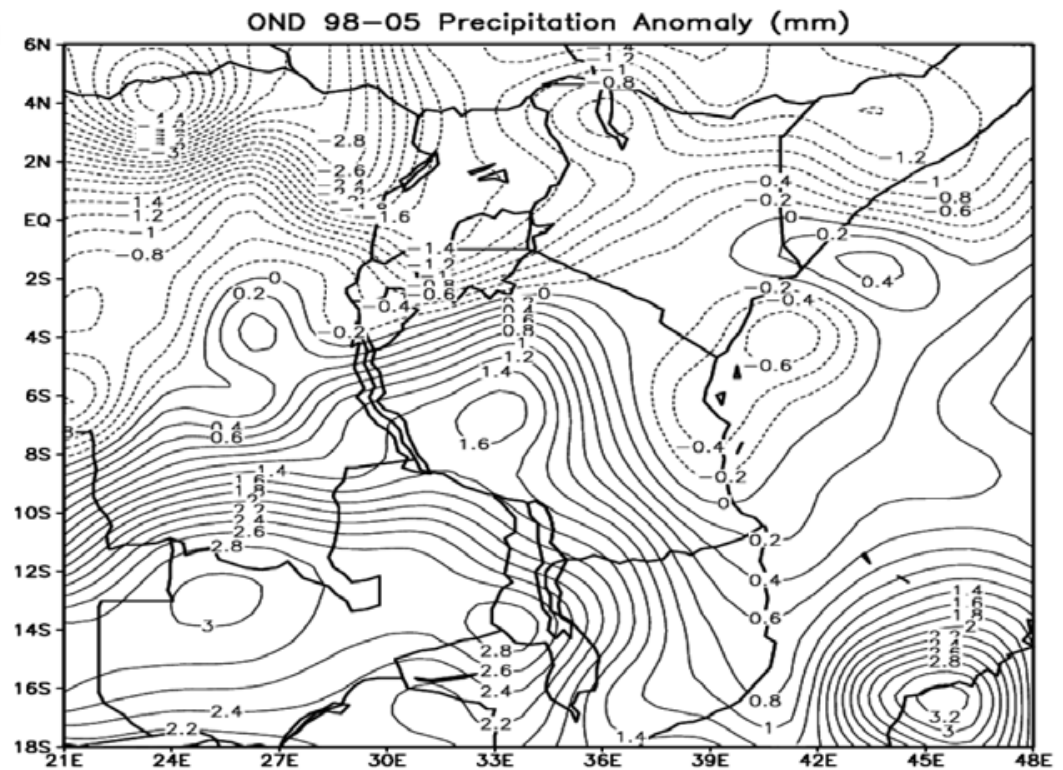

b

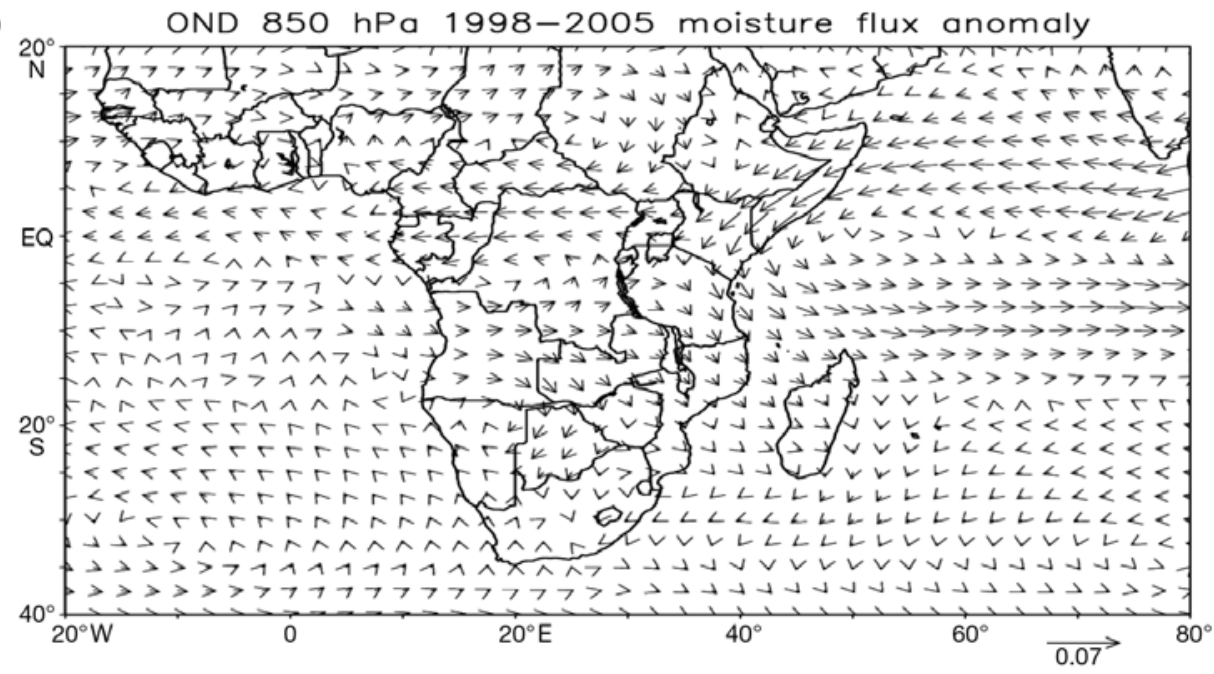

C

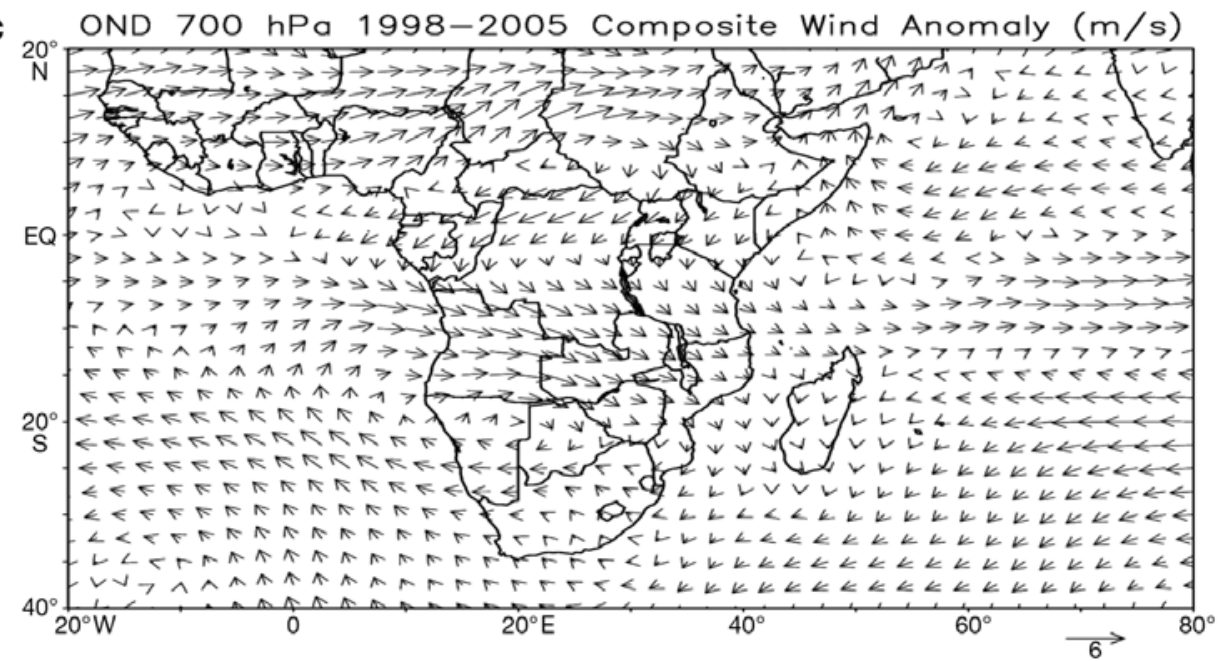

Fig. 4. OND 1998 to 2005 composite anomalies for: (a) CMAP rainfall (mm) (negative anomalies in dashed contours), (b) moisture flux at $850 \mathrm{hPa}$ (a scale vector of $0.07\left[\mathrm{~kg} \mathrm{~kg}^{-1}\right] \mathrm{m} \mathrm{s}^{-1}$ is shown) and (c) wind at $700 \mathrm{hPa}$ (a scale vector of $6 \mathrm{~m} \mathrm{~s}^{-1}$ is shown) 
a OND 98-05 zonal wind Anomaly (35-39E; 2-5S)

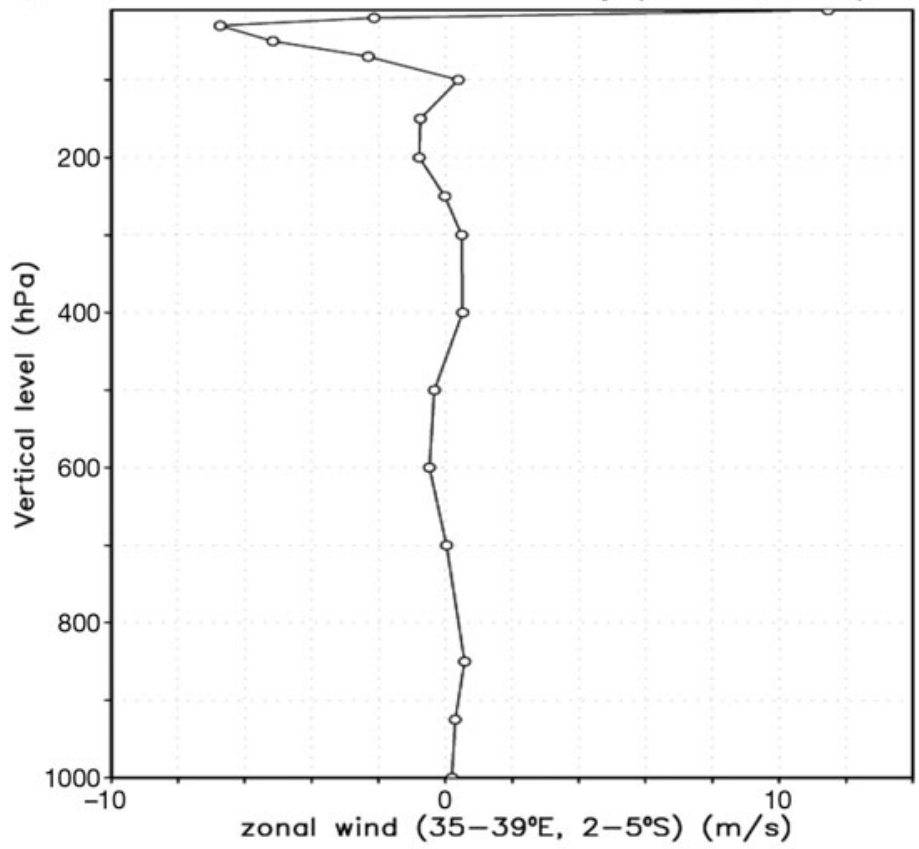

b

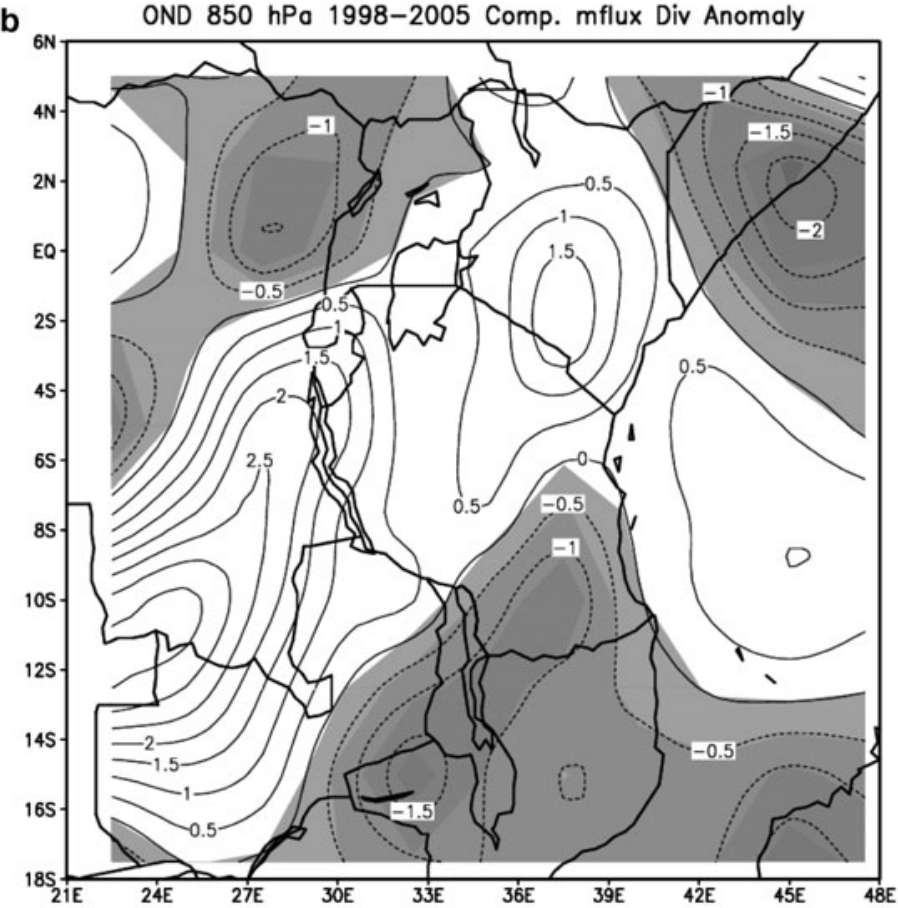

Fig. 5. OND 1998 to 2005 composite anomalies of: (a) zonal wind transect $\left(\mathrm{m} \mathrm{s}^{-1}\right)$ and (b) moisture flux divergence at $850 \mathrm{hPa}\left(10^{-8} \mathrm{~kg} \mathrm{~kg}^{-1} \mathrm{~s}^{-1}\right)$. Areas of convergence are shaded

zania. Again, similar features were observed during both prolonged OND droughts, suggesting that the results presented for 1998 to 2005 are not simply a special case.

In summary, the prolonged drought over the northeastern highlands of Tanzania in OND 1998 to 2005 is related to 2 main factors: (1) Westerly wind anomaly patterns over the western Indian Ocean and easterly wind anomaly patterns over the Congo Basin that transport moisture away from the country. (2) Lowlevel moisture flux divergence and subsidence over northern Tanzania that suppresses convection.

\subsubsection{MAM circulation}

Fig. 8 shows rainfall and wind anomaly fields for the MAM 2000 to 2005 composite. All of Tanzania and East Africa experienced dry conditions (Fig. 8a). At $850 \mathrm{hPa}$, Fig. 8b shows a zone of easterly moisture flux anomalies over the equatorial western Indian Ocean between 2 and $15^{\circ} \mathrm{S}$, veering to southerly anomalies over eastern Tanzania. This pattern is coupled with an easterly anomaly over the Congo Basin that diverts moisture away from Tanzania.

At 850 (not shown) and 700 hPa levels (Fig. 8c), southerly wind anomalies cover much of Kenya and eastern Tanzania. These patterns indicate the dominance of southerly anomalies that transport moisture away from the country, by running parallel to the coast, veering to westerly anomalies over Somalia, with easterly anomalies over the Congo Basin. These patterns were confirmed by the zonal wind transects averaged over the region (Fig. 9a) that show westerly anomalies over the region in the lower and middle levels, opposing the mean easterly flow. Strong easterly anomalies occur in the upper level. Comparisons with the OND wind transect indicate stronger anomalies during the MAM season, as expected from the stronger negative rainfall anomalies observed in this season. It should be noted here that the stronger upper-level easterly anomalies imply strong upperlevel convergence with strong subsidence over the region that, in turn, increases the strength of negative rainfall anomalies over the region. Similarly, weaker upper-level easterly anomalies imply weaker subsidence over the region and, hence, a less severe drought. Fig. 9b shows strong moisture flux divergence over much of Tanzania, except in the far southwest, consistent with the drought observed.

Velocity potential and vertical velocity for the MAM 2000 to 2005 composite can be seen in Fig. 10. The position of the descending branch of the Walker type circulation is located over the African region centred at about $30^{\circ} \mathrm{E}$, as identified by negative velocity potential and divergent wind in the lower levels (Fig. 10a). This pattern is coupled with positive velocity potential and convergent wind in the upper levels (Fig. 10b). This suggests strong subsidence over the East African region, which is confirmed by the omega plot (Fig. 10c). The occurrence of strong 

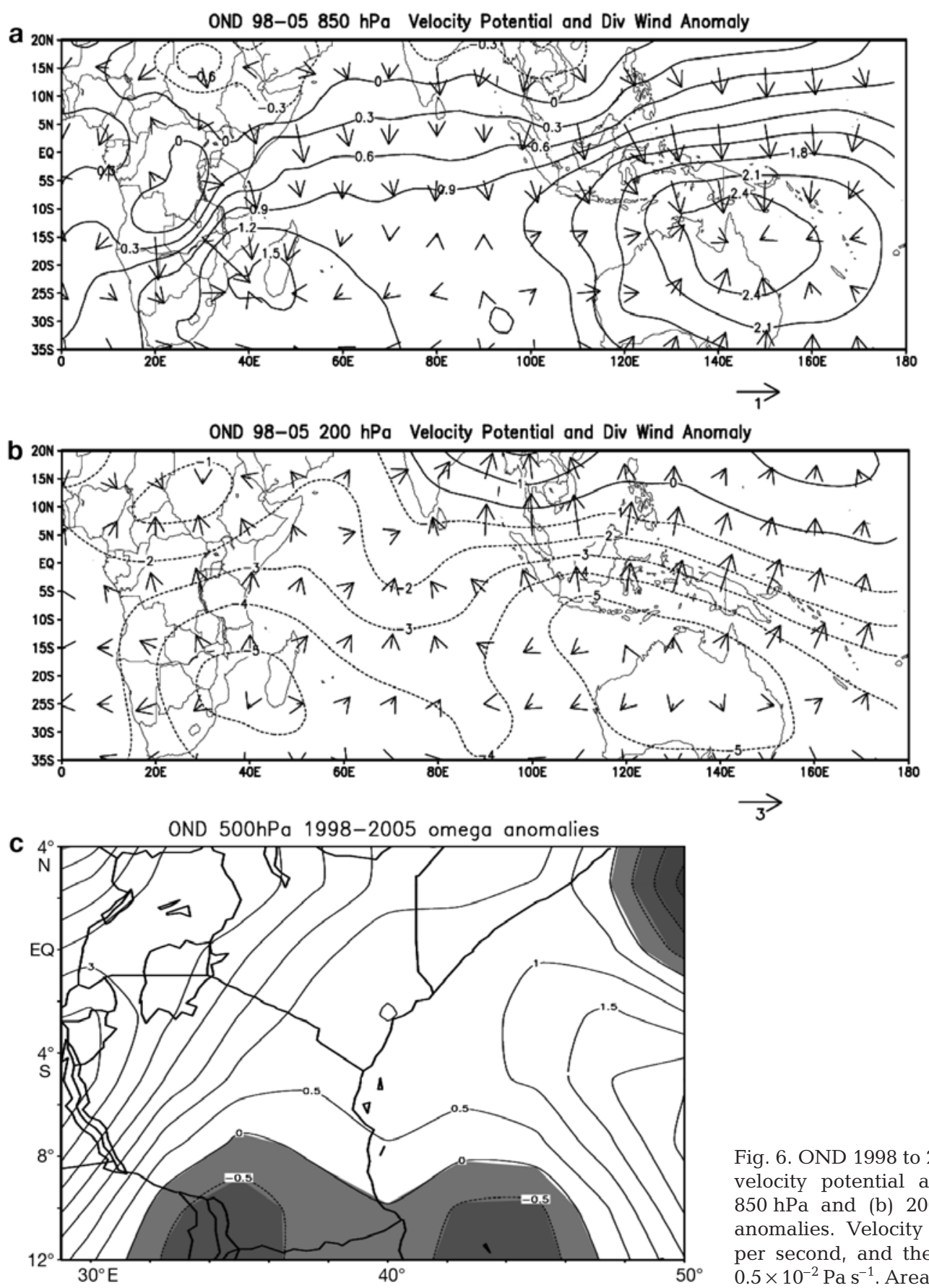

Fig. 6. OND 1998 to 2005 composite anomalies of velocity potential and divergent wind at: (a) $850 \mathrm{hPa}$ and (b) $200 \mathrm{hPa}$; (c) $500 \mathrm{hPa}$ omega anomalies. Velocity potential in square metres per second, and the omega contour interval is $0.5 \times 10^{-2} \mathrm{~Pa} \mathrm{~s}^{-1}$. Areas of relative uplift are shaded

subsidence over the northeastern highlands of Tanzania suggests unfavourable conditions for convection, consistent with the dry conditions over the region.

In summary, the drought over northern Tanzania that occurred during MAM 2000 to 2005 was associated with 2 main factors: firstly, strong moisture flux divergence over the region and, secondly, strong subsidence associated with occurrence of the descending branch of the Walker-type circulation over East Africa.

\subsubsection{Comparison between OND and MAM} circulation patterns

Rainfall data indicate that the rainfall anomalies were stronger during the MAM season. Such stronger rainfall anomalies were associated with strong easterly wind anomalies in the upper level coupled with strong subsidence over the region of study, while, for the OND, the upper-level wind anomalies were weaker. Both the OND and the MAM seasons were charac- 
a
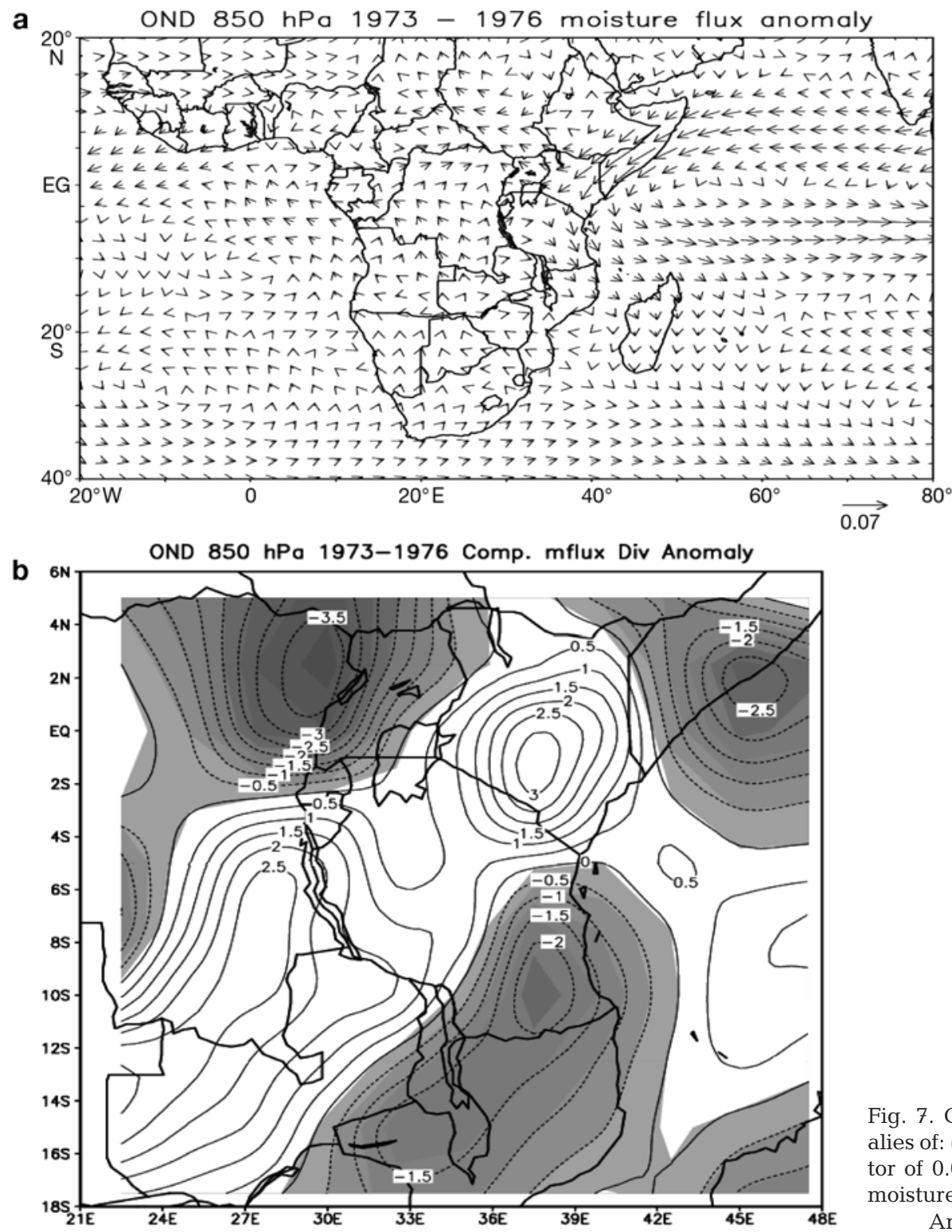

Fig. 7. OND 1973 to 1976 composite anomalies of: (a) $850 \mathrm{hPa}$ moisture flux (a scale vector of $0.07\left[\mathrm{~kg} \mathrm{~kg}^{-1}\right] \mathrm{m} \mathrm{s}^{-1}$ is shown) and (b) moisture flux divergence $\left(10^{-8} \mathrm{~kg} \mathrm{~kg}^{-1} \mathrm{~s}^{-1}\right)$.

Areas of convergence are shaded

terised by westerly wind anomalies over the western Indian Ocean at the $850 \mathrm{hPa}$ level. However, such westerly anomalies were located north of the equator during the MAM season and south of the equator during the OND season. Low-level moisture flux divergence and subsidence over northern Tanzania were common features of both the OND and MAM droughts. Both the moisture flux divergence and the subsidence over the region were unfavourable for convection.

\section{INTRA-SEASONAL VARIABILITY}

Most studies of rainfall variability over East Africa to date have concentrated on seasonal to inter-annual scales. This part of the study investigates the intra- seasonal spells of drier and wetter conditions recorded over the northeastern highlands of Tanzania during the 1998 to 2005 drought.

\subsection{Pentad rainfall climatology time series}

Daily rainfall data from 4 stations were first grouped into $5 \mathrm{~d}$ means (pentads). The grouping was done on a monthly basis so that the last pentad of a month has $6 \mathrm{~d}$ for a month with $31 \mathrm{~d}$, while for a leap year the last pentad of February has $4 \mathrm{~d}$. Time series of averaged pentad rainfall for the period from 1971 to 2005 were plotted. The criteria for rainfall onset, peak and cessation dates used in Kijazi \& Reason (2005) were adopted. 

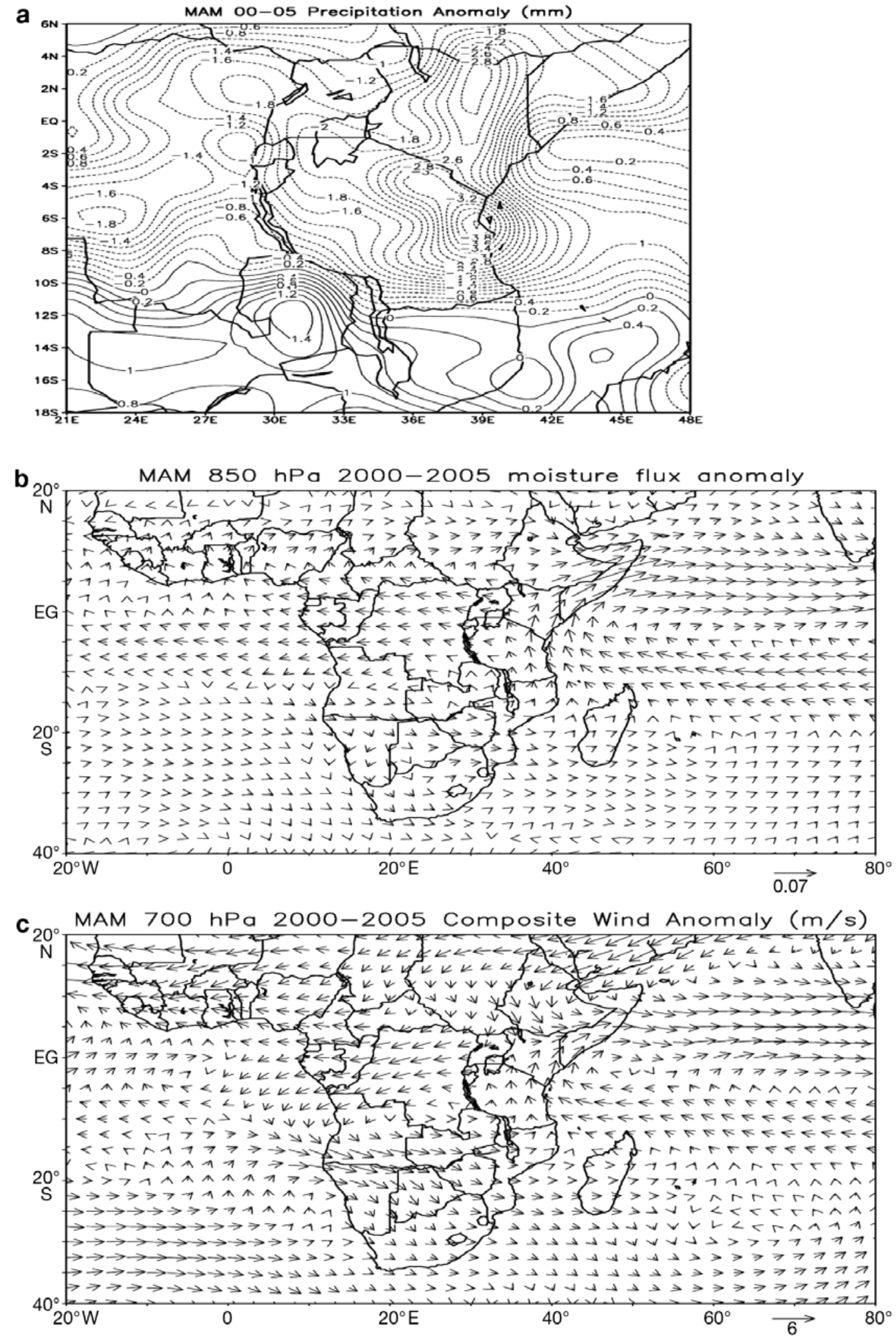

Fig. 8. MAM 2000 to 2005 composite anomalies of: (a) CMAP rainfall (mm) (negative anomalies in dashed contours), (b) moisture flux at $850 \mathrm{hPa}$ (a scale vector of $0.07\left[\mathrm{~kg} \mathrm{~kg}^{-1}\right] \mathrm{m} \mathrm{s}^{-1}$ is shown) and (c) wind at $700 \mathrm{hPa}$ (a scale vector of $6 \mathrm{~m} \mathrm{~s} \mathrm{~s}^{-1}$ is shown) 
For comparative purposes, CMAP pentad rainfall data were averaged between 8 and $4^{\circ} \mathrm{S}, 38.5$ and $41^{\circ} \mathrm{E}$ for the northern coast. The following criteria were used for the selection of onset, peak, end and major dry spells for the OND and MAM seasons. These criteria have been in use over the country during Tanzania Meteorological Agency (TMA) seasonal rainfall outlook forums since 2005 and are appropriate for local agricultural and water resource needs.

Short rain season (OND): Onset: Rainfall over $5 \mathrm{~d}$ $\geq 7.5 \mathrm{~mm}$, followed by 3 consecutive pentads having a

a

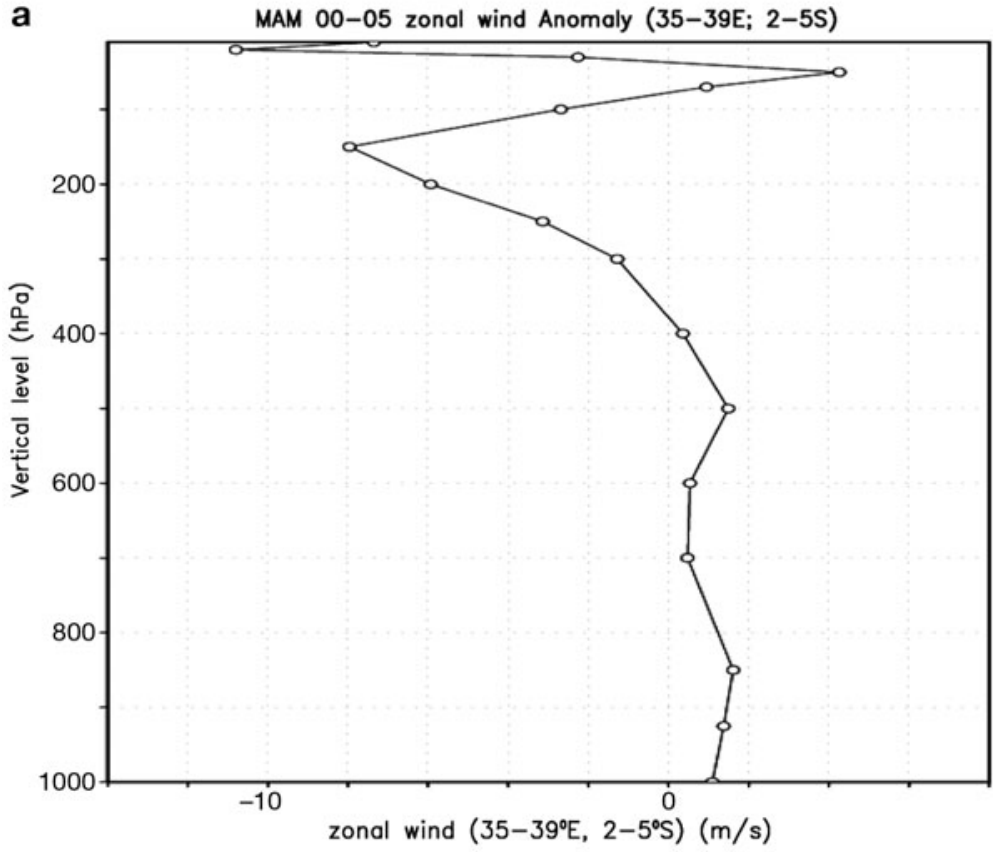

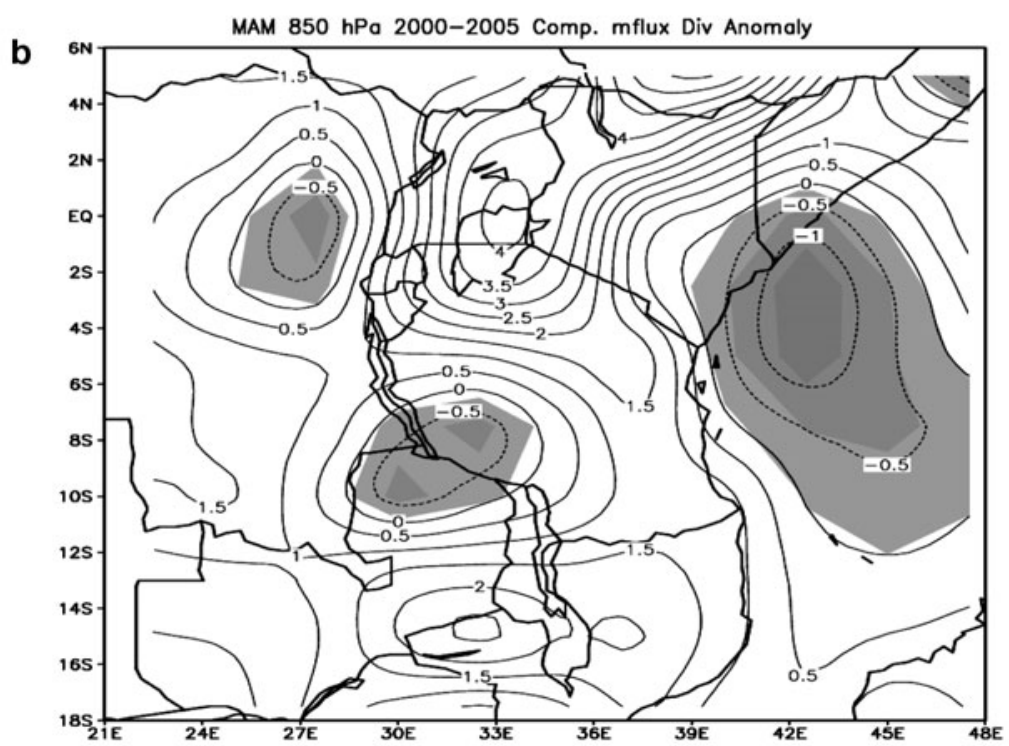

Fig. 9. MAM 2000 to 2005 composite anomalies of: (a) zonal wind transect $\left(\mathrm{m} \mathrm{s}^{-1}\right)$ and (b) moisture flux divergence at $850 \mathrm{hPa}\left(10^{-8} \mathrm{~kg} \mathrm{~kg}^{-1} \mathrm{~s}^{-1}\right)$. Areas of convergence are shaded rainfall amount of $\geq 5 \mathrm{~mm}_{\text {pentad }}{ }^{-1}$. Peak: The pentad with the highest amount of rainfall in the season. End: If 3 consecutive pentads have a mean rainfall $\leq 2 \mathrm{~mm} \mathrm{~d}^{-1}$, the preceding pentad is considered to be the end of the rain season. Dry spell: Rainfall over $5 \mathrm{~d}$ of $<7.5 \mathrm{~mm}$.

Long rain season (MAM): Onset: Rainfall over $5 \mathrm{~d}$ $>10 \mathrm{~mm}$, followed by 3 consecutive pentads with a rainfall amount of $\geq 10 \mathrm{~mm}$ pentad $^{-1}$. Peak: The pentad with the highest amount of rainfall in the season. End: If 3 consecutive pentads have mean rainfall $\leq 2 \mathrm{~mm} \mathrm{~d}^{-1}$, the preceding pentad is considered to be the end of the rain season. Dry spell: Rainfall over $5 \mathrm{~d}$ of $<10 \mathrm{~mm}$.

The climatological time series (Fig. 11) indicates that, on average, the onset of the OND rainfall season occurs on the 60th pentad ( 26 to 31 October); the peak, on the 66th pentad (26 to 30 November); and it ceases on the 3rd pentad (11 to 15 January). The total amount of rainfall received, on average, during the OND season is $180 \mathrm{~mm}$.

For the MAM season, the climatological onset is on the 15th pentad (11 to 15 March); the peak, on the 22 nd pentad (16 to 20 April); and the mean cessation date is the 29th pentad (21 to 25 May). The total amount of rainfall received, on average, is $388 \mathrm{~mm}$.

\subsection{Pentad rainfall time series during OND 2003 and MAM 2004}

An analysis for each year during the 1998 to 2005 droughts was also undertaken, but, for the sake of brevity, only the driest period, namely 2003/2004, is presented here. However, the scrutiny of yearly plots (not shown) demonstrates that each year has its own rainfall characteristics, especially in terms of the duration of the rainfall season and amount of rainfall received. In most of the years, the rainfall season completely failed, and the criteria for the onset and cessation of the rainfall season were not met, highlighting the severity of the drought.

The pentad rainfall time series for OND 2003 is illustrated in Fig. 12a. Scrutiny of the time series indicates that the rainfall onset criteria were not met. Rainfall of about $2 \mathrm{~mm} \mathrm{~d}^{-1}$ was observed at the 65th pentad (21 to 25 November), followed by 3 consecutive dry pentads. A significant amount of rainfall of about $7 \mathrm{~mm} \mathrm{~d}^{-1}$ was 
a
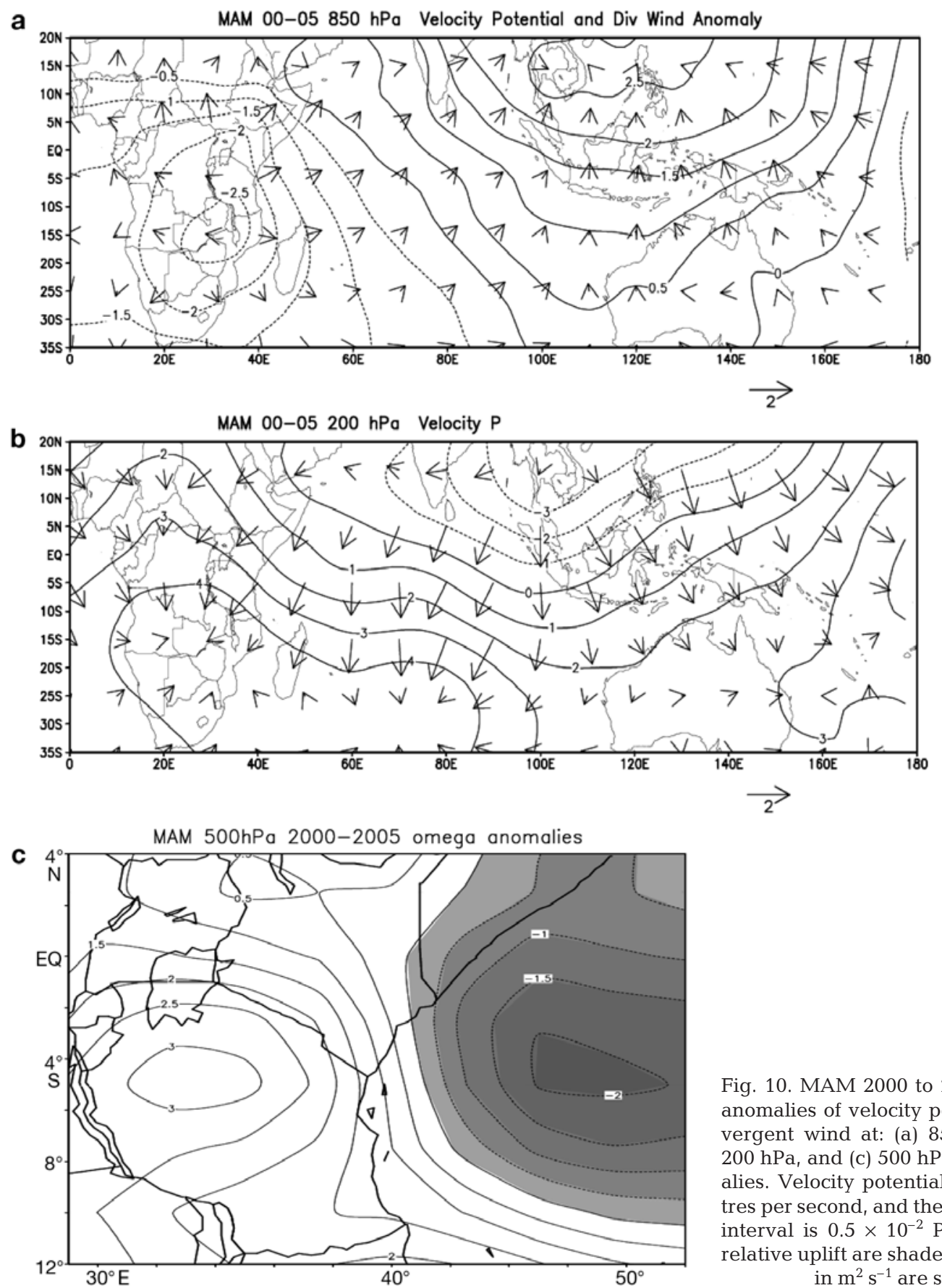

Fig. 10. MAM 2000 to 2005 composite anomalies of velocity potential and divergent wind at: (a) $850 \mathrm{hPa}$ and (b) $200 \mathrm{hPa}$, and (c) $500 \mathrm{hPa}$ omega anomalies. Velocity potential in square metres per second, and the omega contour interval is $0.5 \times 10^{-2} \mathrm{~Pa} \mathrm{~s}^{-1}$. Areas of relative uplift are shaded. Scale vectors in $\mathrm{m}^{2} \mathrm{~s}^{-1}$ are shown

observed during the 69th pentad (11 to 15 December), followed by an out of season peak at the 3rd pentad (11 to 15 January) of about $9 \mathrm{~mm} \mathrm{~d}^{-1}$. In some years, the out of season peak is significant and helps to minimise the impact of the drought. For example, in the year 2000 (not shown), there was a shift of the rainy season from OND to November-January (NDJ), with a peak of rainfall in January. About $164 \mathrm{~mm}$ of rainfall was observed in January 2001, which was near the OND average. During 2000/2001, the total amount of rainfall received in NDJ was $292 \mathrm{~mm}$, which was above the OND average.

During the 2004 MAM season (Fig. 12b), the rainfall onset was on the 14 th pentad (6 to 10 March); the peak, on the 21st pentad (11 to 15 April); and cessation, on the 24th pentad (26 to 30 April). Compared to the climatological dates for onset (11 to 15 March) and cessation (21 to 25 May), the rainfall season was much shorter than average. Similarly, the total amount of rainfall received was below average (169 mm) com- 
a

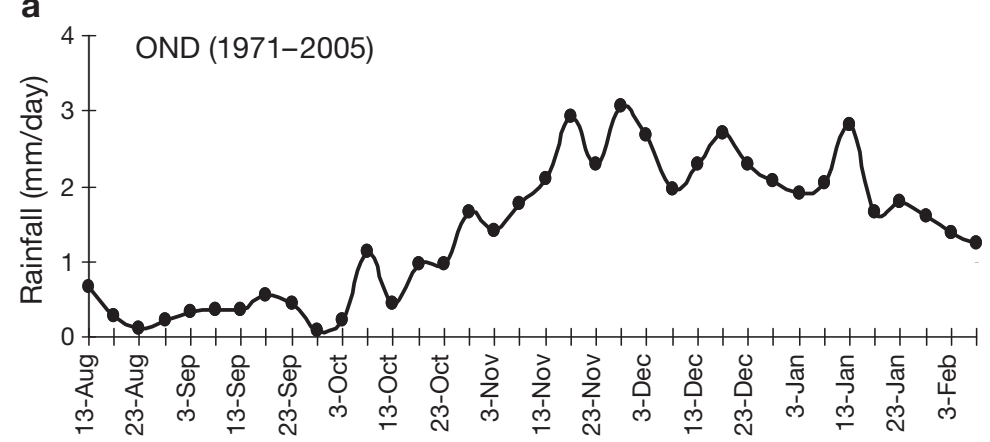

b

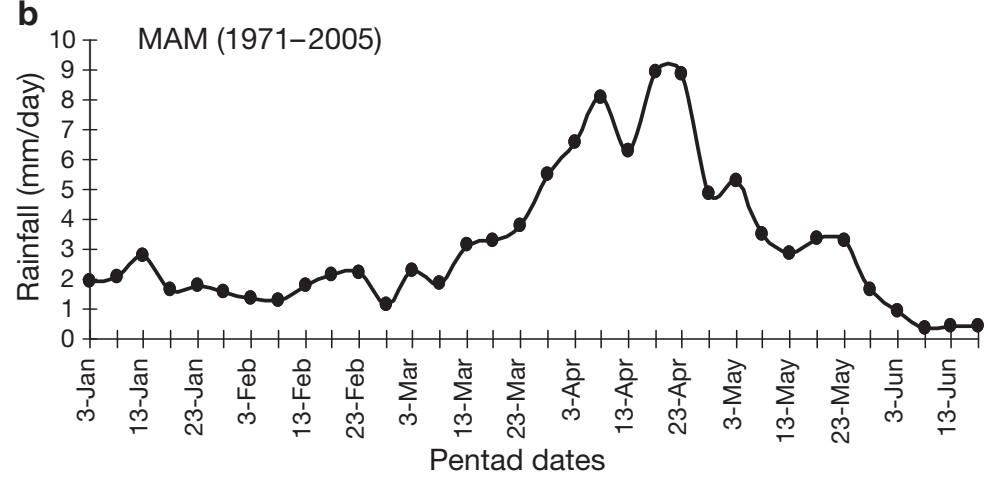

Fig. 11. Time series of climatological pentad rainfall for the northeastern highlands of Tanzania
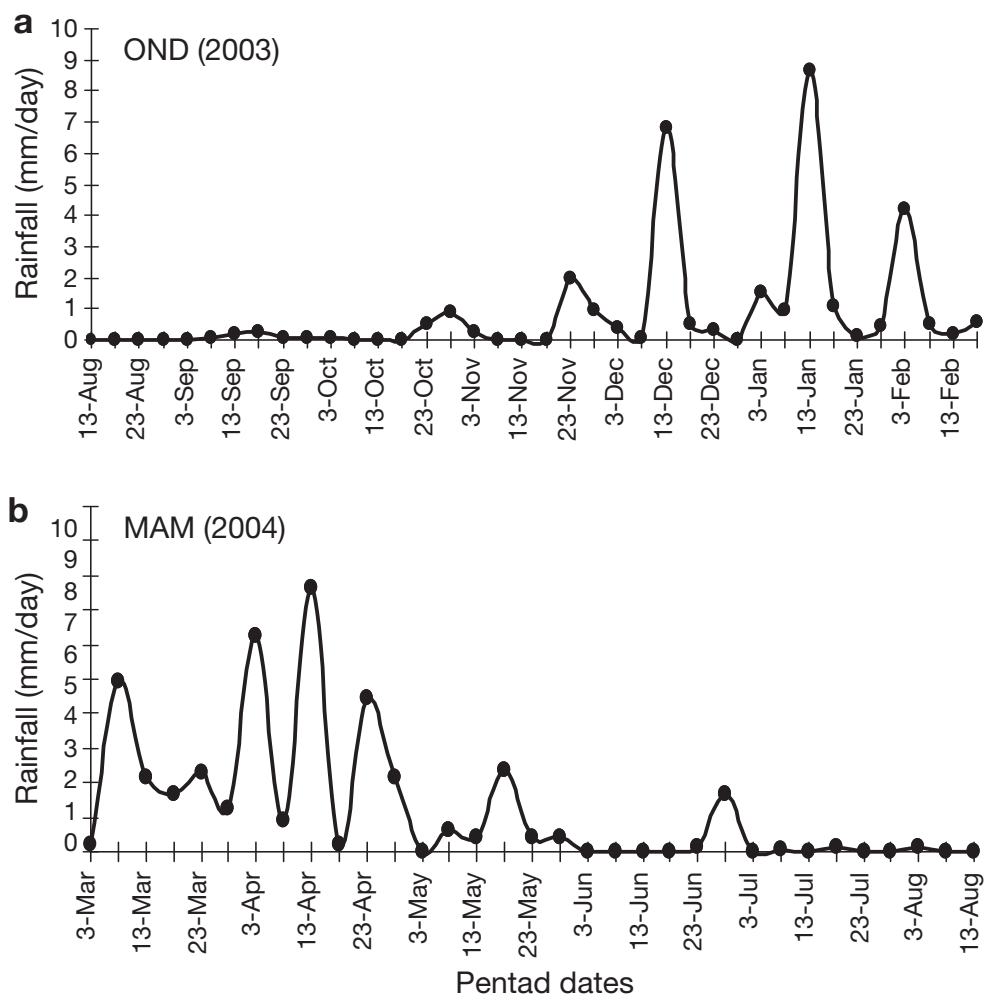

Fig. 12. Time series of pentad rainfall for the northeastern highlands of Tanzania during dry years pared to the climatological average of about $388 \mathrm{~mm}$. Furthermore, the season was characterised by frequent dry spells (16 to 20 March, 6 to 10 April, and 16 to 20 March), while climatologically (Fig. 11b) there are no dry spells during this season.

\section{CONCLUSIONS}

The characteristics of the inter-annual and intra-seasonal rainfall variability over the northeastern highlands of Tanzania and their associated circulation anomaly patterns during the 1998 to 2005 droughts have been analysed. It is evident that the 1998 to 2005 drought was characterised by a complete failure of both rainfall seasons. The rainfall onset was undefined in most of the years, with unevenly distributed rains associated with prolonged periods of dry spells within the shorter-than-average seasons. Such droughts had devastating effects, most notably crop failures and livestock losses that resulted in food shortage. Another major effect was the reduction in the level of the country's dams, which resulted in hydroelectric power and water rationing. The Drought Impact Assessment (2006) reported widespread death of animals over the region that was associated with the prolonged drought.

During the short rainy season, a displacement of the rains from OND to NDJ was observed, with occasional, strong wet spells in January or even February (e.g. Fig. 12a). In fact, most of the years $(1998,2000,2001,2003$ and 2004) had an out-of-season rainfall peak in January, which was important for agriculture and may be used to mitigate the impact of drought over the country. The circulation anomalies indicate that the observed drought over northern Tanzania was associated with 3 main factors: (1) wind circulation patterns that diverted moisture away from the country; (2) strong moisture flux divergence over the region; (3) strong subsidence associated with an eastward shift in the ascending limb of the Walker-type circulation. Similar atmospheric circulation patterns were observed over the region during the 1973 to 1976 prolonged drought, suggesting that the results presented here are not simply a special case, but may have relevance to other multi-year droughts and thus may have some predictability based on the atmospheric circulation patterns. 
Acknowledgements. We thank the members of the NCEP reanalysis project for making available the very useful reanalysis data to the whole scientific community. Funding from the Third World Organization for Women in Science (TWOWS) is gratefully acknowledged. We thank all reviewers whose comments greatly improved the manuscript.

\section{LITERATURE CITED}

Anderson D (1999) Extremes in the Indian Ocean. Nature 401:337-339

Bjerknes J (1969) Atmospheric teleconnections from the equatorial Pacific. Mon Weather Rev 97:163-172

Camberlin P (1995) June-September rainfall in north-eastern Africa and atmospheric signals over the tropics: a zonal perspective. Int J Climatol 15:773-783

Camberlin P, Wairoto JG (1997) Intraseasonal wind anomalies related to wet and dry spells during the long and short rainy seasons in Kenya. Theor Appl Climatol 58:57-69

Chen T, Yen M (1991) Interaction between intraseasonal oscillations of the midlatitude flow and tropical convection during 1979 northern summer; the Pacific Ocean. J Clim 4:653-671

Christina OC, Webster PJ, Cole JE (2002) Interdecadal variability of the relationship between the Indian Ocean zonal mode and East African coastal rainfall anomalies. J Clim 16:548-554

DIA (Drought Impact Assessment) (2006) An experience over north eastern highlands and central areas of Tanzania. Bulletin Issue No. 6 (January-March), Tanzania Meteorological Agency, Dar es Salaam

Goddard L, Graham NE (1999) Importance of the Indian Ocean for simulating rainfall anomalies over eastern and southern Africa. J Geophys Res 104(D16):19099-19116

Hastenrath S, Nicklis A, Greischar L (1993) Atmospheric hydrospheric mechanisms of climate anomalies in the western equatorial Indian Ocean. J Geophys Res 98 (C11): 20219-20235

Hastenrath S, Dierk P, Mutai C (2007) Diagnosing the 2005 drought in equatorial East Africa. J Clim 20:4628-4637

Ininda J (1984) Spatial and temporal characteristics of drought in eastern and southern Africa. MSc thesis, University of Nairobi, Nairobi

Janowiak JE (1988) An investigation of interannual rainfall. J Clim 1:240-255

Kabanda TA, Jury MR (1999) Inter-annual variability of short rains over northern Tanzania. Clim Res 13:231-241

Kalnay E, Kanamitsu M, Kistler R, Collins W and others (1996) The NCEP/NCAR 40-year Reanalysis Project. Bull Am Meteorol Soc 77:437-471

Kijazi AL, Reason CJC (2005) Relationships between intraseasonal rainfall variability of coastal Tanzania and ENSO. Theor Appl Climatol 82:153-176 doi:10.1007/s00704-0050129-0

Kiladis GN, Diaz HF (1989) Global climatic anomalies associated with extremes in the Southern Oscillation. J Clim 2:1069-1090

Krishnamurti TN, Kanamitsu M, Koss WJ, Lee JD (1973) Tropical east-west circulation during the northern winter. J Atmos Sci 30:780-787

Mapande AT, Reason CJC (2005) Links between rainfall variability on intraseasonal and interannual scales over western Tanzania and regional circulation and SST patterns. Meteorol Atmos Phys 89:215-234

Mhita MS (1990) The analysis of rainfall data for agriculture in Tanzania. TMRP Res Rep No. 2/90, Directorate of Meteorology Tanzania, Dar es Salaam

Editorial responsibility: Gerd Esser,

Gießen, Germany
Minja WSM (1982) The weather anomalies during northern summers of 1972 and 1978 over Africa. In: Proc Tech Conf Climate of Africa, Arusha. World Meteorological Organisation, Geneva, p 195-208

Mistry VV, Conway D (2003) Remote forcing of East African rainfall and relationships with fluctuations in levels of Lake Victoria. Int J Climatol 23:67-89

Newell RE, Kidson JW, Vincent DG, Boer GJ (1972) The general circulation of tropical atmosphere and interaction with extra tropical latitudes, Vol 1. MIT Press, Cambridge, MA

Nicholson SE (1996) A review of climate dynamics and climate variability in eastern Africa. In: Johnson TC, Odata E (eds) Limnology, climatology and paleoclimatology of the East African lakes. Gordon \& Breach Publishers, New York

Nicholson SE, Entekhabi D (1987) Rainfall variability in equatorial and southern Africa: relationships with sea surface temperatures along the southwestern coast of Africa. J Clim Appl Meteorol 26:561-578

Nieto R, Gimeno L, Trigo RM (2006) A Lagrangian identification of major sources of Sahel moisture. Geophys Res Lett 33:L18707

Nieuwolt S (1978) Rainfall and drought frequencies in East Africa. Erdkunde 32:81-88

Nyenzi BS (1992) El Niño/Southern Oscillation (ENSO) fluctuations and its influence to southern Africa climate. In: Proc 1st SADC Conf Climate Change. Windhoek, Namibia, p 25-27

Ogallo LJ (1984) Temporal fluctuations of seasonal rainfall patterns in East Africa. Mausam 35:175-180

Ogallo LJ (1988) Relationship between seasonal rainfall in East Africa and Southern Oscillation. J Climatol 8:34-43

Ogallo LJ (1989) The spatial and temporal patterns of the East African seasonal rainfall derived from principal component analysis. Int J Climatol 9:145-167

Ogallo LJ, Ambenje PG (1996) Monitoring drought in eastern Africa. WMO/TD No. 753, World Meteorological Organisation, Geneva

Ogallo LJ, Nassib IR (1984) Drought patterns and famines in East Africa during 1982-1983. In: 2nd WMO Symp Meteorological Aspects of Tropical Droughts. World Meteorological Organisation, Geneva, p 41-44

Okoola RE (1999) A diagnostic study of the eastern Africa monsoon circulation during the Northern Hemisphere spring season. Int J Climatol 19:143-168

> Reason CJC, Allan RJ, Lindesay JA, Ansell TA (2000) ENSO and climatic signals across the Indian Ocean basin in the global context. Int J Climatol 20:1285-1327

Riehl H (1979) Climate and weather in the tropics. Academic Press, London

Ropelewski CF, Halpert MS (1987) Global and regional scale precipitation patterns associated with the El Nino/Southern Oscillation. Mon Weather Rev 115:1606-1626

Saji NH, Goswami BN, Vinayachandran PN, Yamagata T (1999) A dipole mode in the tropical Indian Ocean. Nature 401:360-363

Stoeckenius T (1981) Interannual variations of tropical precipitation patterns. Mon Weather Rev 109:1233-1247

Webster PJ (1983) Mechanisms of monsoon low-frequency variability: surface hydrological effects. J Atmos Sci 40: $2110-2124$

Webster PJ, Moore AM, Loschnigg JP, Leben RR (1999) Coupled ocean-atmosphere dynamics of the Indian Ocean during 1997-98. Nature 401:356-360

> Xie P, Arkin PA (1997) Global precipitation: a 17-year monthly analysis based on gauge observations, satellite estimates and numerical model outputs. Bull Am Meteorol Soc 78:2539-2558

Submitted: January 17, 2008; Accepted: November 27, 2008

Proofs received from author(s): February 23, 2009 